\title{
A QUALITATIVE RESEARCH ON PERCEIVED AUTHENTICITY OF CORPORATE SOCIAL RESPONSIBILITY
}

\author{
DOI: 10.17261/Pressacademia.2019.1174 \\ JMML- V.6-ISS.4-2019(3)-p.225-238
}

\author{
Gozde Nur Kazazoglu Sahin ${ }^{1}$, Sebnem Burnaz ${ }^{2}$ \\ ${ }^{1}$ Istanbul Technical University, Management Department, Istanbul, Turkey. \\ gozde.kazazoglu@gmail.com,ORCID ID: 0000-0003-2187-9352 \\ ${ }^{2}$ Istanbul Technical University, Management Department, Istanbul, Turkey. \\ burnaz@itu.edu.tr, ORCID ID: 0000-0002-4845-4031
}

Date Received: October 30, $2019 \quad$ Date Accepted: December 22, 2019

To cite this document

Kazazoglu Sahin, G.N., Burnaz, S. (2019). A qualitative research on perceived authenticity of corporate social responsibility. Journal of Management, Marketing and Logistics (JMML), V.6(4), p. 225-238.

Permemant link to this document: http://doi.org/10.17261/Pressacademia.2019.1174

Copyright: Published by PressAcademia and limited licenced re-use rights only.

\begin{abstract}
Purpose - With the increasing CSR efforts and consumer skepticism towards CSR, a deeper understanding regarding the dimensions behind the perceived authenticity of CSR becomes vital. With this purpose, current paper explores the dimensions of perceived authenticity in CSR domain from the perspective of consumers and company executives in a developing country context.

Methodology - Current paper reviews the previous literature on perceived authenticity of CSR efforts and includes in-depth interviews with company executives responsible of CSR efforts from a sample of local and multinational companies operating in Turkey, and consumer focus groups, using in vivo and provisional coding in the first degree, and focused coding in the second degree with respondent validation.

Findings- This paper's findings indicate that perceived authenticity of consumers for CSR efforts is influenced by congruence, commitment, candidness and community link as previous research emphasized. This paper contributes to the literature by bringing creativity of CSR effort and consumer's engagement with the CSR effort forth as two new dimensions affecting the perceived authenticity of CSR.

Conclusion- Detailed exploration of perceived authenticity of CSR efforts advances the research and may help to impair the widening authenticity gap between the perceptions of the business and society in CSR domain in a developing country context.
\end{abstract}

Keywords: corporate social responsibility, perceived authenticity, perceived innovativeness, consumer experience, focus group JEL Codes: M14, M31

\section{INTRODUCTION}

Corporate social responsibility's importance for companies has been constantly increasing since 1990s. In 2017, Fortune Global 500 companies spend over $\$ 15$ billion a year on corporate philanthropy and spearhead a wide variety of corporate social responsibility (CSR) initiatives (Skroupa, 2017). Furthermore, for the first time in the history, all industry sectors show a healthy rate of CSR reporting with every sector's reporting rate over 60\% in 2017 (KPMG, 2017).

Unfortunately, despite all these efforts, not every company gets CSR concept right. In addition, even not every good CSR effort is able to create the positive social impact it would like to create for company's stakeholders as we have experienced in Dove's "Real Beauty" project. In this CSR project, the concept of six different 'body-shaped' bottles to celebrate body diversity were created, but stakeholders labelled the concept offensive and patronizing, thus the project never realized and never reached the aimed impact or change. Similarly, in Pepsi's advertisement with Kendall Jenner joining a non-specific protest march, ending with her handing a can of Pepsi to a police officer, the message seemed cynical, inauthentic and trivialized serious protests (Solon, 2017).

As Werther and Chandler (2005) and Agudelo et al. (2019) emphasized, CSR today becomes a strategic necessity based on a genuine commitment and self-analysis, instead of a minimal commitment with a short-term benefit. Although literature shows that CSR generally creates positive outcomes in financial performance (Orlitzky et al, 2003), corporate reputation (Brammer and 
Pavelin, 2006), re-purchase intention (McWilliams et al., 2006) and brand attitude (Ferrell et al., 2018); stakeholders may view one CSR effort positively and hold a negative opinion for another one (Aguilera et al., 2007; Peloza and Shang, 2010). Meaning that although a company may act in a socially responsible manner, it does not necessarily show that the company is perceived as socially responsible (Mohr et al., 2001; Webb and Mohr, 1998). The case of ExxonMobil is an unfortunate example of this probability where cutting a check to its foundation to help promote "global health, education and economic opportunity" is not perceived as social responsibility since the stakeholders' could not link the effort to its core business and no empathy derived for the CSR.

Literature shows that when CSR is perceived merely as a window dressing strategy (greenwashing), consumer skepticism increases, and therefore companies' stakeholders develop negative perceptions (perception of inauthenticity) and reactions that harm the companies by even hurting the brand loyalty and re-purchase intention (Aguinis and Glvas, 2013; Bavik, 2019).

That is why the concept of authenticity as well as understanding the dimensions of authenticity become a necessity for the companies to implement right CSR projects, and to be perceived as genuine. Although authenticity is examined in various marketing literature (Mazutis and Slawinski, 2014; Perez, 2019), the understanding of its role in the context of CSR moved forward first with Alhouti et al.'s (2016) research and recently with Joo et al.'s (2019) research on CSR authenticity antecedents and outcomes.

Though the research on CSR in developing countries are increasing, it is still profoundly under-researched (Visser 2009) Additionally, as Fernando and Lawrence (2015) argue, literature on management and CSR shows that contextual structural differences such as historical, cultural and customary traditions, and organizational, industrial and even level of economic development partly drive people and businesses to perceive and practice CSR in different ways (Hofstede, 1980; Hofstede, 2001; White, 2008; Azmat and Zutshi, 2012). CSR effort of organizations is not only a business decision but also a cultural or managerial approach based on decisions affected by the expectations of the consumers' and stakeholders' themselves. Thus, this paper, as a first to deep dive perceived authenticity concept in CSR in Turkey, maps the dimensions constructing the authenticity perception of consumers and the companies in CSR. To satisfy the dearth of research which surveys the nature and extent of CSR efforts in developing countries, this paper designed a qualitative research to explore whether the dimensions discussed in the literature sufficiently reflect consumer and company perceptions, and to further investigate whether any other dimension had been underlooked so far.

\section{LITERATURE REVIEW}

Defined as the quality of being true in substance, being original, first hand and prototypical (Molleda, 2010), and staying true to one's self (Morhart et al., 2014); the literature emphasizes that the authenticity represents the reality and being inherent in the object itself (Schallehn et al., 2014) and totally objective. Contrary to these arguments, some researchers define authenticity as something perceived, as a function of the perceived genuineness and positive valuation of an object in the mind of perceivers (Chiu et al., 2012). Thus, these researchers defend that authenticity exists if and only if a person subjectively believes the authenticity of an object (Lewis and Bridger, 2000).

Authenticity construct has also recently gained some attention in the management literature, specifically in the fields of marketing and leadership (Avolio and Gardner 2005; Beverland and Farrelly 2010; Liedtka 2008). In marketing, authenticity refers broadly to "being true to oneself" such that one's actions and behaviors are aligned with one's core values and beliefs (Gardner et al. 2005; Harvey et al. 2006). However, one must be true to oneself within a social context in which others identify and accept these values and beliefs as appropriate (Eagly 2005). At the company level, scholars have examined the tensions that companies face when they strive to be distinct while also fitting into accepted social and cultural traditions (Maurer et al. 2011) and how both distinctiveness and being connected to one's social context are critical to authenticity in organizations (Liedtka 2008).

As Peterson underlines "authenticity is a claim that is made by or for someone, thing, or performance and either accepted or rejected by relevant others" (2005, p. 1086). Similarly, in the context of leadership, Goffee and Jones $(2005$, p. 86) argue that "authenticity is a quality that others must attribute to you." Stakeholders not only help the company to discover its authentic self, but also validate claims made by the organization about its authenticity, and that is exactly why this paper favor authenticity as perceived and subjective construct.

Defining CSR authenticity as "the perception of a company's CSR actions as a genuine and true expression of the company's beliefs and behavior towards society that extend beyond legal requirements," Alhouti et al. (2016) used to be the first who identified the factors that influence the perceived authenticity of CSR initiatives. Although earlier than Alhouti et al., Godfrey (2005) and 
Beckman et al. (2009) discussed various indicators as Table 1 shows. Alhouti et al. (2016) proposed a measure of CSR authenticity and found four distinct drivers which are impact, perceived motives, reparation and the fit. In 2005, Godfrey has suggested stability, transparency and responsiveness as the three indicators of the genuineness of CSR; where in 2009, Beckman et al. emphasized impact of business on all stakeholders, addressing to social needs of the country, being visible in the community, stability, transparency, consistency and to be embedded in the fabric of the firm as factors increasing the authenticity in the eyes of stakeholders. Table 1 depicts the studies focusing on the indicators of perceived authenticity of CSR efforts.

Table 1: Perceived Authenticity Indicators of CSR Efforts in the Literature

\begin{tabular}{|c|c|c|}
\hline Literature & Indicator & Result \\
\hline $\begin{array}{l}\text { Alhouti et al. (2016); Beckman et al } \\
\text { (2009); Liedtka (2008); Mazutis and } \\
\text { Slawinski (2014); Menon and Kahn } \\
\text { (2003); Simmons and Becker-Olsen } \\
\text { (2006) }\end{array}$ & $\begin{array}{l}\text { Fit (Image Fit/Functional Fit), } \\
\text { alignment, consistency, } \\
\text { distinctiveness }\end{array}$ & $\begin{array}{l}\text { CSR authenticity is positively influenced by fit of } \\
\text { brand, vision, and mission, and image of the } \\
\text { company with the CSR effort. }\end{array}$ \\
\hline $\begin{array}{l}\text { Chang (2008); Alhouti et al. (2016); Joo } \\
\text { et al (2019) }\end{array}$ & $\begin{array}{l}\text { Contribution, impact, broad } \\
\text { impact }\end{array}$ & $\begin{array}{l}\text { Consumers show positive reactions to higher } \\
\text { donation amounts. } \\
\text { CSR authenticity is positively influenced by } \\
\text { impact. }\end{array}$ \\
\hline $\begin{array}{l}\text { Ellen, Webb, and Mohr (2006); Alhouti et } \\
\text { al. (2016); Beverland (2006); Spiggle et al } \\
\text { (2012), Joo et al (2019) }\end{array}$ & $\begin{array}{l}\text { Perceived motives, } \\
\text { benevolence }\end{array}$ & $\begin{array}{l}\text { CSR authenticity is positively influenced by the } \\
\text { altruistic motives of the company for CSR efforts. }\end{array}$ \\
\hline $\begin{array}{l}\text { Beckman et al. (2009); Gofrey (2005), } \\
\text { Moulard et al (2016); Joo et al (2019) }\end{array}$ & Long term orientation & $\begin{array}{l}\text { CSR authenticity is positively influenced by the } \\
\text { long-term commitment of company to CSR } \\
\text { effort. }\end{array}$ \\
\hline $\begin{array}{l}\text { Beckman et al (2009), Mazutis and } \\
\text { Slawinski (2014); Godfrey (2005), Joo et } \\
\text { al (2019), Bonsu (2018); Liedtka (2008) }\end{array}$ & $\begin{array}{l}\text { Community link, social } \\
\text { connectedness, } \\
\text { responsiveness }\end{array}$ & $\begin{array}{l}\text { CSR authenticity is positively influenced by the } \\
\text { increased community link of CSR effort, its' } \\
\text { connectedness with the society and its } \\
\text { responsiveness to the society needs. }\end{array}$ \\
\hline $\begin{array}{l}\text { Beckman et al (2009); Basu and Palazzo } \\
\text { (2008); Godfrey (2005); Wicki and Kaaij } \\
\text { (2007; Morsing and Schultz (2006); }\end{array}$ & $\begin{array}{l}\text { Transparency, honesty, } \\
\text { truthful }\end{array}$ & $\begin{array}{l}\text { CSR authenticity is positively influenced by } \\
\text { transparency. }\end{array}$ \\
\hline $\begin{array}{l}\text { Alhouti et al. (2016); Basu and Palazzo } \\
\text { (2008); Wagner et al (2009); Joo et al. } \\
\text { (2019). }\end{array}$ & Reliability & $\begin{array}{l}\text { CSR authenticity is positively influenced by the } \\
\text { reliability between what the company says and } \\
\text { does. }\end{array}$ \\
\hline
\end{tabular}

As authenticity refers to whether a company's CSR efforts are genuine, meaning whether they are tied to the organization's values and whether they are connected to societal norms and expectations; stakeholders are more likely to trust an organization's CSR efforts if they perceive them to be authentic (Wicki and van der Kaaij 2007). Failing to be perceived as authentic and genuine, companies are criticized for not "walking their CSR talk" (Lyon and Montgomery, 2015), and even "greenwashing" (Bowen, 2014) leading to intentional ethical deviance.

Furthermore, it is emphasized that the skepticism and mistrust towards the CSR efforts, can lead to distrust towards the company (Bechman et al., 2009; Goffee and Jones, 2005; Mintzberg, 1983); hurt retailer equity, create negative word of mouth towards the company and can negatively relate to resilience to negative information of the company (Skarmeas and Leonidou, 2013). Thus, the perceived authenticity of the CSR efforts is extremely critical in terms of its consequences and outcomes for the company and for the brand.

As authenticity improves message and source credibility by reducing consumer skepticism and enhancing brand loyalty, and positively influencing trust and company reputation (Bhattacharya and Sen, 2004; Lichtenstein, Drumwright, and Braig, 2004; Madrigal and Boush, 2008; Alhouti et al.,2016; Abbas, Shah, and Gao, 2018), perceived authenticity positively influences the purchase intention, thus leading to positive financial outcomes (Lichtenstein, Drumwright, and Braig, 2004; Alhouti et al., 2016; Mohr and Webb, 2005; Murray and Montanari, 1986). Table 2 below indicates possible outcomes of perceived authenticity towards CSR efforts. 
Table 2: Outcomes of Perceived Authenticity towards CSR Efforts in the Literature

\begin{tabular}{|c|c|c|}
\hline Literature & Indicator & Result \\
\hline $\begin{array}{l}\text { Bhattacharya and Sen (2004); } \\
\text { Lichtenstein, Drumwright, and Braig } \\
\text { (2004); Madrigal and Boush (2008); } \\
\text { Alhouti et al. (2016); Abbas, Shah,and } \\
\text { Gao (2018); }\end{array}$ & $\begin{array}{l}\text { Loyalty, trust and } \\
\text { reputation. }\end{array}$ & $\begin{array}{l}\text { CSR authenticity positively influences brand } \\
\text { loyalty. } \\
\text { CSR authenticity positively influences trust. } \\
\text { CSR authenticity positively influences company } \\
\text { reputation. }\end{array}$ \\
\hline $\begin{array}{l}\text { Alhouti et al. (2016); Godfrey et al } \\
\text { (2008); Samuel et al (2018). }\end{array}$ & $\begin{array}{l}\text { Boycott behavior, resilience } \\
\text { to negative information }\end{array}$ & $\begin{array}{l}\text { CSR authenticity negatively influences boycott } \\
\text { behavior. }\end{array}$ \\
\hline $\begin{array}{l}\text { Lichtenstein, Drumwright, and Braig } \\
\text { (2004); Alhouti et al. (2016); Mohr and } \\
\text { Webb (2005), Murray and Montanari } \\
\text { (1986) }\end{array}$ & $\begin{array}{l}\text { Purchase intention, positive } \\
\text { financial outcomes }\end{array}$ & $\begin{array}{l}\text { CSR authenticity positively influences purchase } \\
\text { intent. }\end{array}$ \\
\hline $\begin{array}{l}\text { Romani, Grappi, and Bagozzi (2013); Joo } \\
\text { et al. (2019) }\end{array}$ & Positive WOM & $\begin{array}{l}\text { CSR authenticity positively influences positive } \\
\text { WOM. }\end{array}$ \\
\hline Romani, Grappi and Bagozzi (2013) & $\begin{array}{l}\text { Gratitude towards the } \\
\text { organization }\end{array}$ & $\begin{array}{l}\text { CSR authenticity positively influences the feeling } \\
\text { of gratitude towards the company. }\end{array}$ \\
\hline Joo et al. (2019) & Willingness to support CSR & CSR authenticity positively influences \\
\hline
\end{tabular}

\section{DATA AND METHODOLOGY}

After identifying the potential dimensions of perceived authenticity of CSR efforts based on extant literature search, we employed a qualitative research design to understand whether the dimensions underlined in literature sufficiently reflect consumer perceptions, and to further explore whether any other dimension had been under looked. Thus, we specifically focused on the nature of CSR, definition of authentic CSR, what factors companies consider to be perceived as more authentic, how consumers really perceive the CSR efforts of the companies, and how perceived authenticity affects the consumer perception towards the CSR activities. Analysis of the company executives' responses to face-to-face in-depth interview questions and analysis of the consumers' responses in the focus groups yielded important insights related to companies' strategies in implementing CSR efforts, consumers' perceived authenticity of CSR efforts and consumer's willingness to support the cause.

\subsection{Research Design}

An exploratory research approach is adopted to be able to reach deep and rich information in an area which seems underresearched in terms of the relation of authenticity with CSR activities. The study includes a range of well-established multinationals and local companies who are well-known for their corporate social citizenship efforts in Turkey (GfK, 2018). The corporates who are invited to participate the research are selected from the GfK's "Corporate Social Responsibility Research 2018" based on their recognition in CSR by the stakeholders. In overall, authors contacted with 20 corporates and eight of them accepted to participate the research, with an acceptation rate of $40 \%$. These companies included four multinationals from fast moving consumer goods, insurance, technology and energy, while three national conglomerates operating in industries from manufacturing to energy and construction, and the last participant company was a local consultancy company serving in corporate citizenship strategies.

We used purposive sampling and expected this sampling methodology to afford us maximum opportunities for making comparable analysis (Strauss and Corbin, 1998) of companies from a variety of industries and experiences with stakeholders, as well as integrating multinationals' and locals' point of views in implementing CSR. The snowballing method is used to recruit a heterogeneous group of corporate officials from the departments of corporate communications and corporate citizenship. It is aimed to understand how corporates perceive corporate social responsibilities and what kind of strategies and priorities they are taking into consideration for their CSR projects, and whether they prioritize authenticity in their CSR projects and how they are trying to arouse this perception of being authentic for their stakeholders.

In our initial sampling phase, we mailed explanatory and invitational e-mails about our study to several companies' manager level contacts we have previously have communication with, asking them to accept the interview and distribute the letters to potential 
participants if they approved of our interviewing. On receipt of this approval, one-to-one, face-to-face interviews are scheduled with the related respondents, and obtained their informed consent. Overall, the three of the respondents were the heads of corporate communications department, where the remaining five of the participants were either senior specialist or junior manager in corporate communications department responsible of CSR.

This sampling method was quite satisfactory thanks to the nature of the relationships of the company executives who contacted them. Personal contact from familiar colleagues/professionals within corporate and the hierarchy inside the company have influenced the respondents' willingness to participate and support.

In-depth interviews' data were collected via semi structured questionnaires, which Fontana and Frey (1994) described as "one of the most powerful ways in which we try to understand our fellow human beings" (p. 645). Face-to-face interviews occurred in the respondents' offices and ranged in length from 90 to 120 minutes. The interview questions given in Appendix focused on CSR strategies and projects, factors considered while implementing the projects, also managers' understanding of consumers' perceived authenticity for their CSR efforts. Interviews with company executives could not be taped due to the reasons of confidentiality. Therefore, interviews progressed slowly to maintain the researcher take necessary notes. In addition, four of the participants also provided briefly written answers to our questions after the interviews.

Focus groups on the other hand, are taped and the consent of the participants are taken in advance of the study. In total four focus groups (total $n=23$ with six per group for all but one group with five participants) are conducted. As Table 3 shows, focus group participants ranged in age from 21 to 56; 78\% were female; 61\% were high school and below graduate. Semi-structured, open-ended questions asked to the focus group participants are listed in Appendix and each focus group ranged in the length from 80 min to 100 minutes

Table 3: Demographic Characteristics of the Focus Group Participants

\begin{tabular}{|l|c|c|}
\hline & Focus Group Participants & Frequency \\
\hline Gender & 18 & \\
\hline Female & 5 & $78 \%$ \\
\hline Male & & $22 \%$ \\
\hline Age & 3 & \\
\hline $18-25$ & 8 & $13 \%$ \\
\hline $26-40$ & 11 & $35 \%$ \\
\hline $41-55$ & 1 & $48 \%$ \\
\hline $55+$ & & $4 \%$ \\
\hline Education & 9 & $39 \%$ \\
\hline Primary School & 5 & $22 \%$ \\
\hline High School & 6 & $26 \%$ \\
\hline University & 3 & $13 \%$ \\
\hline MA/PhD & & \\
\hline Income & 12 & $52 \%$ \\
\hline$<3000 T L$ & 6 & $26 \%$ \\
\hline $3001-4500 T L$ & 5 & $22 \%$ \\
\hline$>4501 T L$ & & \\
\hline
\end{tabular}

\subsection{Data Analysis and Data Confirmability}

The written-up field-notes and transcripts were then analyzed by hand, identifying dominant concepts that were repeatedly mentioned by consumers and company executives. The hand analysis is preferred since we wanted to be close to the data and have a hands-on feel for it without the intrusion of a machine, also considering the inquiry is in local language (Gibbs and Taylor, 2005; Saldana, 2013). 
Based on Saldana's "The Coding Manual for Qualitative Researchers", we preferred in vivo and provision coding in the first degree since the former one draws from the participants own language for codes, prioritize and honor the participant's voice (Stringer, 1999; Saldana, 2013) while the latter one "imply actions intertwined with the dynamics of time, such as those things that emerge, change, occur in particular sequences, or become strategically implemented through time" (Hennink, Hutter, and Bailey, 2011, p. 253; Saldaña, 2003). As a second-degree coding, focused coding used since it categorizes coded data in the first degree on thematic or conceptual similarity (Saldana, 2013).

We also engaged in method of respondent validation (Creswell, 2002) to confirm findings. To secure respondent validation, a summary of findings is presented to the four participants representing each focus group, by face to face, asking them if they concurred with any or all the emergent perspectives, that is, if they saw their personal perspectives represented in any or all of the reported findings. Those focus group participants are especially chosen due to their close attention to the topic during the focus group and high participation in comparison to other focus group participants.

\section{FINDINGS AND DISCUSSION}

Since this paper used in vivo coding prioritizing and honoring the participant's voice, the findings from company executives' interviews and consumer focus groups are firstly categorized by the participant's own wordings ${ }^{1}$. The identification of potential dimensions of the CSR authenticity led the authors to generate a $6 \mathrm{C}$ model (congruence-commitment-candidness-community linkcreativity-consumer engagement) to cluster the findings of the study.

\subsection{Congruence}

Congruence or fit in the literature is defined as "the degree to which stakeholders perceive an alignment between the organization and its CSR efforts" (Alhouti et al., 2016; Joo et al., 2019; Mazutis and Slawinski, 2014; Yoo and Lee, 2018). Yoo and Lee also (2018) indicates that higher the CSR fit, the more favorable the consumers' evaluation of the company (Speed and Thompson, 2000). Furthermore, Alhouti et al. (2016, p. 1244) emphasize that "fit is a factor in perceptions of authenticity when the CSR act does not align with what the firm sells...because it sells a product that is harmful to the cause it promotes"; showing that the non-fit or noncongruency can be a factor to increase the skepticism and the mistrust towards the company, which can lead to devastating outcomes for the company.

Correspondingly, both the consumers and the company executives perceived congruence as an important factor of authenticity since the image fit, functional fit and mission/vision fit of the company with the CSR effort makes the effort more efficient and sustainable considering the experience and the resources that company history and expertise brings in that specific area, as participants highlighted;

"It is really important for me to have a consistency between the CSR project and the product of the company. For example, [company name] producing chocolates and all packaging good, but they implement a CSR project where they motivate people to have a more active life, doing sports. This creates an oppositeness, which I always make fun of..."

"In general, companies are trying to compensate the points they have missed with their daily operations. For example, this oil company, [company name], wanted to implement a project to save dolphins, but actually they were the ones who are causing the marine pollution."

"I perceive [company name] campaign very authentic, and genuine. Because they came to us for personal hygiene and puberty training, they always gave the same message with their brand. They want to strengthen girls and women."

"I also really loved the last ad of because first \%90 of the ad is from actual images, shares his own harassment case. And this spurt is high-toned behavior because it differentiates the brand from its counterparts using women as an object. This is a shaker move of societal taboos, and this is the [brand name]'s role in my perspective, making the best men can be."

\subsection{Commitment}

Commitment construct in this paper focuses on two main dimensions which are long term orientation and the result orientation of the CSR efforts.

\footnotetext{
${ }^{1}$ The names of the companies, brands and CSR programs that the focus group participants and in-depth interview participants discussed are not shared in this article due to ethical concerns, and kept confidential regarding the companies, brands and CSR programs image.
} 
Long term orientation of the company towards the CSR effort is defined as the degree to which stakeholders perceive the organization as dedicated, and committed to designated CSR efforts for long years to come as consumers commented;

"Let's say today I am the Santa Clause, and I brought toys to the children. But I brought it only for one year. What is then?"

"Companies should support the same cause for a life-time. Why do we remember [company name and brand name] or [company name and CSR program] project? Because they have implemented the project for more than 10-20 years. We got educated on personal hygiene in high school with [brand name]. We have seen the results of the [company name] project, that girls got schooled became primary school teachers in eastern villages. These are not one-time supported projects, these are investments to the community, society."

"For me it is important to be sustainable, to be trustful, to focus on one problem and to come up with a strong solution is extremely important."

"As it says, give a man a fish and you feed him for a day; teach a man to fish and you feed him for a lifetime. This must be the mindset of implementing a CSR project. You can give people the fish if it is an urgency, but other than that you need to teach them."

As the comments on long-term orientation are read, it is inevitable not to realize that long-term orientation and result-orientation go together, and they are an inseparable whole. Participants highly focus on the result-orientation of the CSR by commenting as;

"I only have one question on my mind. Does the needy really get the donation? Does the needy really benefit from the project?"

"Sometimes you just have doubts and you want to do some donation by your own, to touch the lives by your own, to be sure, to see the results. These are immediate results. But of course, you cannot change lives in a sustainable manner all alone, there are deeper societal issues that companies need to put resource behind."

"For example, again, [company name and CSR program] project. We see the results we know lives have changed. In a sustainable manner."

Furthermore, company executives emphasized that being result-oriented is critical in the sustainability of the CSR to evaluate and to ameliorate the CSR effort.

"Of course, we need to design key performance indicators, trainings, management systems for all of our CSR efforts. We need to control and analyze the results of our CSR efforts, measure its impact and work continuously to develop our results."

\subsection{Candidness}

Long-term orientation and result-orientation of the CSR effort inspirit another construct which candidness is, derived from French candide, and Latin candidus; meaning honesty and forthrightness. Thus, this construct includes the dimension of transparency referring to the access of stakeholders to information about the company's past, current and planned CSR efforts, and whether the information presented is balanced, rather than biased (Basu and Palazzo 2008). Transparency of the CSR efforts is perceived as an extremely important dimension by consumers, and this is mainly due to the previous unfortunate experiences that the society faced within previous years where some well-known NGOs are found out to be highly corrupted.

That is why, consumers mostly emphasize seeing the results, observing transparency in implementation of the CSR efforts by underlining that;

"We need to see results, before/after visuals, reports anything to share with us."

"Today, even as an individual, I can go and ask for money from each of you. But then you will ask me, what I did with the money I collected, right? It is the same thing with the companies. Who knows what has happened to all that money collected?"

On the company side, during the in-depth interviews, companies shared strong details with the results, performance indicators and budgets of their CSR efforts. Though none of the company executives digged down transparency dimension in deep, they have mentioned their disclosures, CSR reports and awards they got from different platforms and stakeholders. By doing so, they communicate their CSR efforts openly with their stakeholders and acknowledge the importance of this open and honest communication. 


\subsection{Community Link}

Community link in the existing literature defined as the degree to which stakeholders perceive CSR to relate to their communities (Beckman et al., 2009; Joo et al., 2019; Mazutis and Slawinski, 2014). Addressing to local needs, emphasized by the consumers, refers to the degree which companies address the issues and the needs of the local community, the degree of giving back to the people within the community that company is operating in (Beckman et al, 2009; Mazutis and Slawinski, 2014; Joo et al., 2019). Participants therefore used the degree to which CSR efforts met local needs as an indicator of perceived authenticity. Godfrey (2005), also indicated community link as "responsiveness" defined as the willingness of companies to adapt their CSR practices to the changing social and economic requirements of their environment. As participants commented;

"Companies are responsible of implementing CSR projects in the society they are operating in. Because they win from this society."

"We are the ones working for those companies. We make them profit. Of course, they need to address the issues of this country first."

"As our religion emphasizes, you should not sleep when your neighbor is hungry. This means that you need to help the people who are closer to you. Additionally, if you come with a project idea supporting abroad when there is need in your country, you can still attract a certain amount of consumer but not the level you can reach with a project addressing local needs."

Interestingly, some of the focus group participants emphasized that the importance of addressing local needs may be undermined in conditions where humanitarian and urgent aid are in need globally. This awareness proves that consumers usually have a set of priority areas in their minds for CSR, donation, volunteering and support but this set of priorities may get affected by external and uncontrollable incidents such as disasters, war, extreme conditions where survival of the individual becomes the highest priority anywhere in the world as this participant indicated;

"We need to look to the humanitarian emergency. Necessity and urgency may change the focus."

"If people in someplace of the world is living on the razor's edge, then there should be no boundaries to support and help them in the first place."

Furthermore, company executives are also fully aware of the importance of delivering solutions to the local needs and issues whether they are local or multinational companies. While multinational companies are implementing specific projects to address the local needs, they even adapt their internationally known projects to the local dynamics such as [company name]'s and [project name] for girls.

"Our CSR projects proves that our company is transparent, open and in relation with the society it is operating in. The projects we have been leading with this vision targets societal issues and needs. We design our CSR projects according to the needs, issues and shortcomings of our country."

\subsection{Creativity}

Innovativeness and creativeness of the CSR effort are two other indicators that are emphasized by the consumers as indicators of the perceived authenticity, which leads to the key contributions of this research, since no other research in the literature (conceptual or empirical) categorized innovativeness or creativeness of the CSR efforts as an indicator of perceived authenticity. Participants reflected ideas about innovativeness and creativeness of the CSR efforts in comments such as;

"First of all, CSR should touch to the conscience. To do so, it must be the first, something that no one ever think of, must bring an innovative solution to the problem. And of course, it should be benevolent. Not to be done for to be done. It must be helpful to the people, in deep."

"For example, [Company name and CSR program] definitely solves an obvious problem of all, and it is very innovative."

"We are living in such an era of the world history, which one can reach to everyone easily with creative ideas. But still, there are companies basically setting up stands, making simple donations or asking for it. This means that you are dwelling on this cause, you are not putting energy behind it. Then why should I?" 
The views of the participants define innovativeness and creativity as efforts that must be put behind to address the societal needs in a more efficient way to attract the interest of the stakeholders and to show company's real willingness to tackle with the issue. Since there is no innovation without the creative thinking, this study perceives creativity as a broader concept in comparison to innovativeness which also includes innovativeness and considers creativity as one of the dimensions of the perceived authenticity of the CSR efforts.

Contrary to the consumers' emphasis, only one company executive slightly mentioned "innovativeness" while explaining their vision and mission with their CSR projects; "as [company name], we aim to produce and implement innovative, human-oriented, result-oriented, measurable and sustainable solutions to the societal and environmental issues together with the cooperation of universities, NGOs and governmental bodies", rather than giving a strong emphasis as the consumers did. This difference in emphasis of innovation between consumers and company executives shows that company executives underestimate the dimension of the creativity in shaping their CSR efforts.

\subsection{Consumer Engagement}

So far in the literature, consumer experience is mostly defined as the consumer's involvement with the cause meaning as the personal connection because he/she or friends/family members have been affected by the cause (Joo et al., 2019). As the life of the consumer impacted by the cause some way, or consumer has a personal connection to the program designed to fight a certain cause, it has been found that the emotional engagement with the cause was positively associated with the attitudes toward the CSR program (Joo et al, 2019; Mcshane and Cunningham, 2012).

"I grew up in a public boarding school with lack of facilities. Thus, I know that [company name] supporting on boarding schools because the owner of the company is also a graduate of our school. Now, whenever I need a product that [company name] also presents, I prefer buying that company's products."

This study's focus group results take this definition one step further and widens the definition of consumer experience with consumer's interaction with the CSR effort throughout the initiative and with the results. While this dimension has not been identified in prior literature, numerous focus group participants highlighted this aspect in their evaluations.

"I would like to see an active experience in CSR project which will make it more attractive for me and will bond me to the cause and to the people, animals who are in need."

"Seeing the kids helped, sharing their happiness as the supporters of the cause, this activity is unmeasurable. For example, I once had the chance to get together with the kids supported for an educational CSR initiative of a company. Seeing that the company executives are really taking care of them, and valuing them, and spending their time with them, not just their money..."

Furthermore, company executives also highlighted the importance of consumer experience as in the following quotes;

"If you would like to take the support of the consumer, you have to activate them and make sure that they are included in some part of the project. You must give them roles, responsibility, and make sure that you ask more than just buying your product. You may even need to make sure that the project is personalized for them."

"Putting everything aside, the most important thing today is to establish an emotional bond with the consumer. It is important to establish projects that create value for consumers."

The findings of this qualitative study contribute to both literature and business practice by improving our understanding on the dimensions of perceived authenticity of CSR efforts in Turkey, an area with a lack of focus so far, on whether the companies CSR efforts and consumer's perception of these efforts coincide or not and finally present a guiding framework to business to consider while implementing CSR efforts.

The findings of this study show that in Turkey,

(a) When the attributes of the perceived authenticity of consumers are asked to the company executives, it is found out that transparency, honesty, being human-oriented, and consistency of the CSR efforts are the most focused indicators for companies with a lack of focus on fit, innovativeness and result-orientation.

(b) Consumers, on the other hand, focused on the fit, long-term orientation, result orientation and transparency in answering for the same attributes. 
Additionally, this study takes existing literature on perceived authenticity of the CSR one step forward with its findings on the dimensions of the consumers' perceived authenticity; putting in the role of creativity of the CSR effort and consumer engagement in the CSR effort. As a result, this study offers a multi-dimensional model on the consumer's perceived authenticity of the CSR effort by proposing the $6 \mathrm{C}$ model below in Figure 1 ; which is constituted on congruence, commitment, candidness, community link, creativity and consumer engagement.

Figure 1: 6C Model of the Perceived Authenticity of the CSR

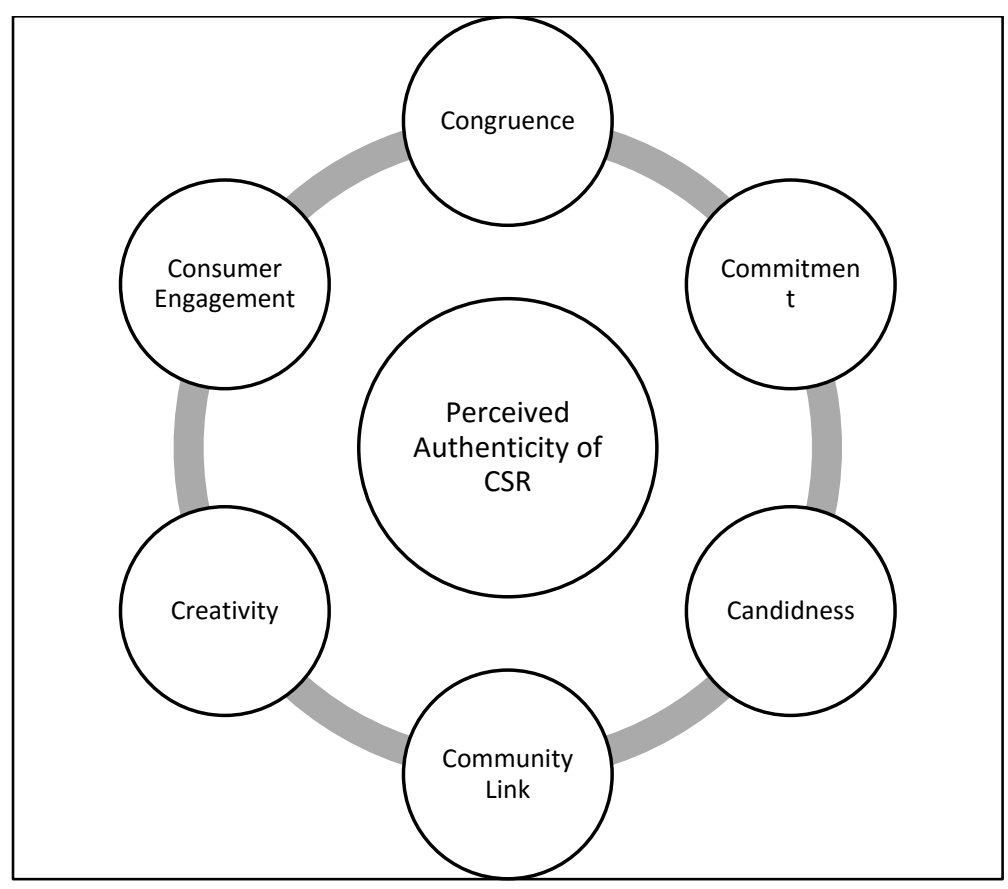

\section{CONCLUSION AND FUTURE RESEARCH}

Our research served to explore the further dimensions of consumer's perceived authenticity of CSR efforts in a developing country like Turkey and to see whether the companies putting these efforts forth fully capture these dynamics or not, and to interpret the factors that companies take into consideration for to be perceived as authentic.

One limitation of this study relates to the recruiting interview and focus group participants through snowball sampling using the network of the researchers. For future research, survey data can be collected with random sampling and from different segments to determine whether the results of the qualitative research can be supported using different samples and data collection methods. In addition, although focus group participants openly shared their thoughts about their willingness to support the CSR effort, the results of the participants could present social desirability bias.

Future research could also study additional dimensions, antecedents and outcomes to those dimensions and include other moderating/mediating variables to further explore such as the perceived corporate character of the multinationals and consumers' individual values. To further contribute to the literature of CSR, multinational companies which implement the exact CSR efforts in different countries and cultures can be examined in terms of perceived authenticity.

Although companies try to build community links to be perceived more authentic (Beckman et al., 2009; Mazutis and Slawinski, 2014), perceived company character of multinationals may have a moderating effect on the perceived authenticity since consumers' perception of company's reputation influences their behavior towards it (Davies et al., 2004). Thus, multinational companies perceived corporate character in every culture may have a direct effect on the perceived authenticity of the CSR efforts. Additionally, personal values also should be taken into consideration in the future studies since values are the beliefs referring to 
desirable goals that motivate action and serve as standards or criteria in decision-making or in evaluation of actions, policies, people, and events (Schwartz, 2012).

\section{REFERENCES}

Abbas, M., Gao, Y., and Shah, S.H. (2018). CSR and customer outcomes: The mediating role of customer engagement. Sustainability. 10, 42434248. doi:10.3390/su10114243

Aguilera, R. V., Rupp, D. E., Williams, C. A., and Ganapathi, J. (2007). Putting the S back in corporate social responsibility: A multilevel theory of social change in organizations. Academy of Management Review, 32(3), 836-863.

Aguinis, H. and Glavas. A. (2013). Embedded versus peripheral corporate social responsibility: Psychological foundations. Industrial and Organizational Psychology, 6(4), 314-332.

Alhouti, S., Johnson, C.M., and Holloway, B.B. (2016). Corporate social responsibility authenticity: Investigating its antecedents and outcomes. Journal of Business Research, 69, 1242-1249.

Avolio, B. J., and Gardner, W. L. (2005). Authentic leadership development: Getting to the root of positive forms of leadership. The Leadership Quarterly, 16(3), 315-338.

Azmat, F. and Zutshi, A. (2012). Influence of home-country culture and regulatory environment on corporate social responsibility perceptions: The case of Sri Lankan immigrant entrepreneurs. Thunderbird International Business Review, 54, 15-27.

Basu, K., and Palazzo, G. (2008). Corporate social responsibility: A process model of sensemaking. Academy of Management Review, 33, $122-136$.

Bavik, A. (2019). Corporate social responsibility and service-oriented citizenship behavior: A test of dual explanatory paths. International Journal of Hospitality Management, 80, 173-182.

Bhattacharya, C. B., and Sen, S. (2004). Doing Better at Doing Good: When, Why, and How Consumers Respond to Corporate Social Initiatives. California Management Review, 47(1), 9-24. https://doi.org/10.2307/41166284

Brammer S. and Pavelin, S. (2006). Corporate reputation and social performance: The importance of fit. Journal of Management Studies, 43(3), 435-456.

Beckman, T., Colwell, A. and Cunningham, P.H. (2009). The emergence of corporate social responsibility in Chile: The importance of authenticity and social networks. Journal of Business Ethics, 86, 191-206.

Beverland, M. B. (2006). The 'real thing': Branding authenticity in the luxury wine trade. Journal of Business Research, 59, $251-258$.

Beverland, M. B., and Farrelly, F. J. (2010). The quest for authenticity in consumption: Consumers' purposive choice of authentic cues to shape experienced outcomes. Journal of Consumer Research, 36, 838-856.

Bonsu, S. (2018). Corporate social responsibility implementation framework. Walden University Dissertation. Derived from: https://scholarworks.waldenu.edu/dissertations

Bowen, F. (2014), After Greenwashing: Symbolic Corporate Environmentalism and Society. Cambridge: Cambridge University Press.

Chang, C. (2008). To donate or not to donate? Product characteristics and framing effects of cause-related marketing on consumer purchase behavior. Psychology and Marketing, 25(12), 1089-1110.

Chiu, H.-C., Hsieh, Y.-C., Kuo, Y.-C. (2012). How to align your brand stories with your products. Journal of Retailing, 88(2), 262-275.

Creswell, J. (2002). Educational research: Planning, conducting, and evaluating quantitative and qualitative research. Upper Saddle River, NJ: Merrill Prentice Hall.

Davies, G., Chun, R., Silva, R., and Roper, S. (2004). A corporate character scale to assess employee and customer views of organization reputation. Corporate Reputation Review, 7(2), 125-146.

Eagly, A. (2005). Achieving relational authenticity in leadership: Does gender matter? Leadership Quarterly, 16(3), 459-474.

Ellen, P. S., Webb, D. J., and Mohr, L. A. (2006). Building corporate associations: Consumer attributions for corporate socially responsible programs. Journal of the Academy of Marketing Science, 34, 147-157.

Fernando, S. and Lawrence, S. (2015). CSR practices: A comparison between a developed and a developing country. Proceedings of The Environmental and Sustainability Management Accounting Network (Eman) Global Conference 2015. 
Ferrell et. al. (2018). Business ethics, corporate social responsibility, and brand attitudes: An exploratory study. Journal of Business Research, 95, 491-501. https://doi.org/10.1016/j.jbusres.2018.07.039

Fontana, A., and Frey, J. (1994). Interviewing: The art of science. In N. Denzin, and Y. Lincoln (Eds.), Handbook of Qualitative Research. Thousand Oaks, CA: Sage Publication, Inc.

Fournier, S. (2009). Lessons learned about consumers' relationships with their brands. In D. J. Maclnnis, C. W. Park and J. R. Priester (Eds.), Handbook of brand relationships (pp. 5-23). Armonk, NY: M.E. Sharpe.

Gardner, W. L., Avolio, B. J., Luthans, F., May, D. R., and Walumbwa, F. (2005). "Can you see the real me?” A self-based model of authentic leader and follower development. The Leadership Quarterly, 16(3), 343-372.

Gfk (2018). Kurumsal Sosyal Sorumluluk 2018 Raporu (CSR 2018 Report). Retrieved from https://www.gfk.com/tr/icgoerueler/report/kurumsalsosyal-sorumluluk-arastirmasi-2018/

Gibbs, G. R., and Taylor, C. (2005). How and what to code. Retrieved from http://onlineqda.hud.ac.uk/Intro_QDA/how_what_to_code.php

Grappi, S., Romani, S., and Bagozzi R.P. (2013). Consumer response to corporate irresponsible behavior: Moral emotions and virtues. Journal of Business Research, 66, 1814-1821.

Godfrey, P. C. (2005). The relationship between corporate philanthropy and shareholder wealth: A risk management perspective. The Academy of Management Review, 30(4), 777-798.

Goffee, R., and Jones, G. (2005). Managing authenticity: The paradox of great leadership. Harvard Business Review, 83(12), 86-94.

Harvey, P., Martinko, M. J., and Gardner, W. L. (2006). Promoting authentic behavior in organizations: An attributional perspective. Journal of Leadership and Organizational Studies, 12(3), 1-11.

Hennink, M., Hutter, I., and Bailey, A. (2011). Qualitative research methods. London: SAGE Publications.

Hofstede, G. (1980). Culture's consequences: International differences in work related values. Beverly Hills, CA: SAGE Publishers.

Hofstede, G. (2001). Culture's consequences: Comparing values, behaviors, institutions, and organizations across nations. Thousand Oaks, CA: SAGE Publishers.

Joo, S., Miller, E.G., and Fink, J.S. (2019) Consumer evaluations of CSR authenticity: Development and validation of a multidimensional CSR authenticity scale. Journal of Business Research, 98, 236-249.

KPMG. (2017). The KPMG Survey of Corporate Responsibility Reporting 2017. Retrieved from https://kpmg.com/crreporting

Latapí Agudelo, M. A., Jóhannsdóttir, L., and Davídsdóttir, B. (2019). A literature review of the history and evolution of corporate social responsibility. International Journal of Corporate Social Responsibility, 4(1). https://doi.org/10.1186/s40991-018-0039-y

Lewis, D., and Bridger, D. (2000). The Soul of the New Consumer: Authenticity - What We Buy and Why in the New Economy. London: Nicholas Brealey Publishing.

Lichtenstein, D.R., Drumwright, M.E. and Braig, B.M. (2004). The effect of corporate social responsibility on customer donations to corporatesupported nonprofits. Journal of Market. 68, 16-32.

Liedtka, J. (2008). Strategy making and the search for authenticity. Journal of Business Ethics, 80, 237-248.

Lyon, T., and Montgomery, A. (2015). The means and end of greenwash. Organization and Environment, 28(2) $223-249$.

Madrigal, R., and Boush, D.M. (2008). Social responsibility as a unique dimension of brand personality and consumers' willingness to reward. Psychology and Marketing, 25(6), 538-564.

Maurer, C., Bansal, P., and Crossan, M. (2011). Creating economic value through social values: Introducing a culturally informed resource-based view.Organization Science, 22(2), 432-448.

Mazutis, D.D., and Slawinski, N. (2014). Reconnecting business and society: Perceptions of authenticity in corporate social responsibility. Journal of Business Ethics, 131, 1-14.

McShane, L., and Cunningham, P. (2012). To thine own self be true? Employees' judgments of the authenticity of their organization's corporate social responsibility program. Journal of Business Ethics, 108, 81-100.

McWilliams, A., and Siegel, D.S., and Wright, P.M. (2006). Corporate social responsibility: Strategic implications. Journal of Management Studies, 43(1), 1-18. 
Menon, S., and Kahn, B. E. (2003). Corporate sponsorships of philanthropic activities: when do they impact perception of sponsor brand? Journal of Consumer Psychology, 13(3), 316- 327.

Mintzberg, H. (1983). The case for corporate social responsibility. Journal of Business Strategy, 4(2), 3-15. https://doi.org/10.1108/eb039015

Mohr, L. A., Webb, D. J., and Harris, K. E. (2001). Do consumers expect companies to be socially responsible? The impact of corporate social responsibility on buying behavior. Journal of Consumer Affairs, 35(1), 45-72.

Molleda, J. (2010). Authenticity and the construct's dimensions in public relations and communication research. Journal of Communication Management, 14(3), 223-236.

Morhart, F., Malär, L., Guèvremont, A., Girardin, F. and Grohmann, B. (2014). Brand authenticity: an integrative framework and measurement scale. Journal of Consumer Psychology, 25(2), 200-218.

Morsing, M., and Schultz, M. (2006). Corporate social responsibility communication: stakeholder information, response and involvement strategies. Business Ethics: A European Review, 15(4), 323-338.

Moulard, J. G., Raggio, R. D., and Folse, J. A. G. (2016). Brand authenticity: Testing the antecedents and outcomes of brand management's passion for its products. Psychology and Marketing, 33(6), 421-436

Murray, K. B., and Montanari, J. R. (1986). Strategic management of the socially responsible firm: integrating management and marketing theory. Academy of Management Review, 11(4), 815-827.

Orlitzky, M., Schmidt, F. L., and Rynes, S. L. (2003). Corporate Social and Financial Performance: A Meta-Analysis. Organization Studies, 24(3), 403441. https://doi.org/10.1177/0170840603024003910

Peloza, J., and Shang, J. (2010). How can corporate social responsibility activities create value for stakeholders? A systematic review. Journal of Academy of the Marketing Science, 39, 117-135. https://doi.org/ 10.1007/s11747-010-0213-6

Perez, A. (2019). Building a theoretical framework of message authenticity in CSR communication. Corporate Communications: An International Journal. https://doi.org/10.1108/CCIJ-04-2018-0051

Peterson, R. (2005). In search of authenticity. Journal of Management Studies, 42(5), 1083-1098.

Saldaña, J. (2003). Longitudinal qualitative research: Analyzing change through time. Walnut Creek, CA: Alta Mira Press.

Saldaña, J. (2013). The coding manual for qualitative researchers. Los Angeles: SAGE Publications.

Schallehn, M., Burmann, C. and Riley, N. (2014). Brand authenticity: model development and empirical testing. Journal of Product and Brand Management, 23(3), 192-199.

Schwartz, S. H. (2012). An overview of the Schwartz theory of basic values. Online Readings in Psychology and Culture, 2, 1. Online: http://dx.doi.org/10.9707/2307-0919.1116

Simmons, C. J., and Becker-Olsen, K. L. (2006). Achieving marketing objectives through social sponsorships. Journal of Marketing, 70 (4), 154-169

Skarmeas, D., and Leonidou, C. N. (2013). When consumers doubt, watch out! The role of CSR skepticism. Journal of Business Research, 66, 18311838.

Skroupa, C.P. (2017). CSR: HOW FORTUNE 500 COMPANIES MEASURE UP. Derived from: https://skytopstrategies.com/csr-fortune-500companies-measure/

Solon, O. (2017). Kendall Jenner's Pepsi ad criticized for co-opting protest movements for profit. April 5, 2017. Derived from: https://www.theguardian.com/fashion/2017/apr/04/kendall-jenner-pepsi-ad-protest-black-lives-matter

Speed, R., and Thompson, P. (2000). Determinants of sports sponsorship response. Journal of the Academy of Marketing Science, 28, 226-238

Spiggle, S., Nguyen, H. T., and Caravella, M. (2012). More than fit: Brand extension authenticity. Journal of Marketing Research, 49, $967-983$.

Stringer, E. T. (1999). Action research (2nd ed.). Thousand Oaks, CA: Sage.

Strauss, A., and Corbin, J. (1998). Basics of qualitative research: Techniques and procedures for developing grounded theory. Thousand Oaks, CA: Sage Publications, Inc.

Visser, W. (2009). Corporate social responsibility in developing countries. https//doi.org/10.1093/oxfordhb/9780199211593.003.0021

Wagner, T., Lutz, R. J., and Weitz, B. A. (2009). Corporate hypocrisy: Overcoming the threat of inconsistent corporate social responsibility perceptions. Journal of Marketing, 73, 77-91. 
Webb, D. J., and Mohr, L. A. (1998). A typology of consumer responses to cause-related marketing: from skeptics and socially concerned. Journal of Public Policy and Marketing, 17(2), 226-238.

Werther, W. B., and Chandler, D. (2005). Strategic corporate social responsibility as global brand insurance. Business Horizons, 48(4), 317-324.

White, A. L. (2008). Culture matters: The soul of CSR in emerging economies. Business for Social Responsibility (BSR).

Wicki, S., and van der Kaaij, J. (2007). Is it true love between the octopus and the frog? How to avoid the authenticity gap. Corporate Reputation Review, 10(4), 312-318.

Yoo, D., and Lee, J. (2018). The effects of corporate social responsibility (CSR) fit and CSR consistency on company evaluation: The role of CSR support. Sustainability, 10, 2956. https://doi:10.3390/su10082956

\section{APPENDIX}

\section{In-depth Interview Questions}

As a company, what kind of corporate social responsibility efforts do you have? What are your current CSR projects?

How do you determine your CSR projects? To what attributes and strategies are you focusing on?

How do you prioritize your stakeholders and CSR focus? Do you implement any short-medium-long term strategic plans?

Have you ever measured the effectiveness of the CSR effort you have implemented? Have you ever analyzed how consumers perceives your CSR efforts? If yes, what are the attributes and criteria you are focusing on and why?

From your company perspective, how does consumers in Turkey react to CSR efforts?

From your company perspective, what are the attributes that shape consumers' perception on CSR efforts?

How do you define the perceived authenticity of the CSR efforts? What could be the factors affecting consumers' perceived authenticity of the CSR effort?

How do you think that consumers' perceived authenticity of the CSR effort affects consumers' attitude towards the company and thus company reputation? What could be the advantages of consumers' increased perceived authenticity for the company?

How do you think the attitude toward the CSR effort changes if consumers' perceived authenticity of the CSR effort increases? What kind of volunteering activities can consumers perform?

\section{Focus Group Questions}

How do you define corporate social responsibility? What are the first words coming to your mind?

What kind of CSR efforts do you remember?

How do you define the role of companies in social responsibility?

How do you define the reasons why companies are investing in CSR? Do you think that they are authentic in implementing CSR efforts?

To what attributes should companies focus on while they are implementing a CSR effort?

What can be the attributes to define a CSR effort as authentic?

Can you share a CSR effort you think as authentic? (or unauthentic) What are the attributes/characteristics of the effort or the company that made you perceived the effort as authentic (or unauthentic)?

To what extent and how do you support the CSR efforts of the firms? Can you share a CSR effort you supported before and how you supported the effort?

Is there anything else you would like to comment on about company's CSR efforts and authenticity of the CSR efforts? 